Marquette University

e-Publications@Marquette

$11-2015$

\title{
Understanding Publics' Perception and Behaviors in Crisis Communication: Effects of Crisis News Framing and Publics' Acquisition, Selection, and Transmission of Information in Crisis Situations
}

Young Kim

Marquette University, young.kim@marquette.edu

Follow this and additional works at: https://epublications.marquette.edu/comm_fac

Part of the Communication Commons

\section{Recommended Citation}

Kim, Young, "Understanding Publics' Perception and Behaviors in Crisis Communication: Effects of Crisis News Framing and Publics' Acquisition, Selection, and Transmission of Information in Crisis Situations" (2015). College of Communication Faculty Research and Publications. 452.

https://epublications.marquette.edu/comm_fac/452 
Marquette University

e-Publications@Marquette

\section{Communication Studies Faculty Research and Publications/College of} Communications

This paper is NOT THE PUBLISHED VERSION.

Access the published version at the link in the citation below.

Journal of Public Relations Research, Vol. 28, No. 1 (2016): 35-50. DOI. This article is (C) Taylor \& Francis and permission has been granted for this version to appear in e-Publications@Marquette. Taylor \& Francis does not grant permission for this article to be further copied/distributed or hosted elsewhere without the express permission from Taylor \& Francis.

\section{Understanding Publics' Perception and Behaviors in Crisis Communication: Effects of Crisis News Framing and Publics' Acquisition, Selection, And Transmission of Information in Crisis Situations}

Young Kim

Manship School of Mass Communication, Louisiana State University, Baton Rouge, Louisiana

\section{ABSTRACT}

This study aims to better understand publics' perception and communicative behaviors in crisis communication. The extant research has overlooked how framing factors and different publics' communicative behaviors directly influence crisis outcomes, including reputation and behavioral intentions. An online experiment with 1,113 participants was conducted to fill the gap. The findings demonstrated that preventable crisis news framing was a strong negative predictor for crisis outcomes. 
Another finding based on Communicative Action in Problem Solving (CAPS) in Situational Theory of Problem Solving (STOPS) revealed that information attending, forwarding, and seeking are positively associated with reputation and behavioral intentions.

Various publics arise and respond to crisis situations differently. During a crisis, publics become the key players in the environment, creating issues that affect them as well as the organization, government, media, and other parties (Kim, Ni, \& Sha, 2008). Understanding the publics and their communicative behaviors is critical because it can be helpful to determine an organization's stance and to develop effective crisis strategies targeted for the different publics (Kim, Kim, \& Cameron, 2012a). Crisis communication researchers have studied how publics perceive, interpret, and respond to the crisis to better understand the publics and their communicative behaviors in crisis situations (An \& Gower, 2009). In particular, crisis news framing research has illuminated how news framing can influence publics' perception and interpretation of the organization, providing crisis managers with useful insights into the appropriate crisis response strategies for effective crisis communication (Holladay, 2009; Liu \& Kim, 2011).

However, the extant research has focused on how crisis news framing plays an important role in the publics' perceived crisis responsibility or attitudes, rather than actual crisis outcomes, reputation, and behavioral intentions (Coombs, 2007b, 2015). Moreover, previous crisis communication research has failed to identify and examine different publics' communicative behaviors (Austin, Liu, \& Jin, 2012). To fill the gap, this study examines how crisis news framing can be connected to reputation and behavioral intentions to better understand the publics' perception in crisis communication. Adopting Communicative Action in Problem Solving (CAPS: a conceptual framework of communicative behaviors), this study investigates how active communication actions predict the crisis outcomes compared to passive communication behaviors (Kim, Grunig, \& Ni, 2010).

\section{Literature review}

\section{Crisis communication and crisis news framing}

A crisis is the perception of an unpredictable event negatively affecting an organization's performance and reputation, as well as its publics (Coombs, 2015; Fearn-Banks, 2011). If the publics believe there is a crisis, then the organization is in a crisis (Coombs, 2009). After a crisis, publics may not only have negative perceptions of the organization's reputationbut also stop buying its products and no longer support the organization (Helm \& Tolsdorf, 2013). Thus, the crisis seriously damages the reputation and negatively affects publics' behavioral intentions toward the organization (Dowling, 2002; Simon, 2009). To reduce and contain such harm and further change perceptions of the crisis or the organization in crisis, the organization communicates strategically with the publics (Reynolds \& Seeger, 2005; Seeger, 2006). The organization's crisis communication includes actual verbal and nonverbal responses to understand and affect publics' perceptions in a crisis by collecting, processing, and disseminating information required to address a crisis situation (Coombs, 2012).

Crisis communication scholars have provided theoretical approaches to guide and help crisis managers understand how to effectively communicate with publics in response to a crisis (Choi \& Chung, 2013; Seeger, 2006). Coombs (2006, 2007b) proposed Situational Crisis Communication Theory (SCCT), which recommends appropriate crisis response strategies to crisis managers. Applying Wiener's (1986) 
attribution theory, SCCT draws upon empirical evidence and tests hypotheses related to how publics' perceptions of crisis situation affect the crisis response and crisis outcomes (Coombs, 2007a). The SCCT literature has demonstrated how crisis response strategies restore an organization's image and reputation (Choi \& Chung, 2013; Claeys, Cauberghe, \& Vyncke, 2010; Coombs \& Holladay, 2002), as well as improve positive behavioral intentions toward the organization (Coombs \& Holladay, 2007, 2008; Laufer \& Jung, 2010). Consequently, the extant SCCT research illuminated how an organization should choose its crisis response strategies by understanding how the publics perceive crises (Choi \& Chung, 2013; Coombs, 2015).

Thus, crisis communication starts with understanding how publics perceive crisis situations (Coombs, 2007a, 2015; Ulmer, Sellnow, \& Seeger, 2014). The perception of a crisis is based upon a crisis type, and the crisis type is "how the crisis is being framed" (Coombs, 2007b, p. 166). Crisis events can be framed into one of three clusters (victim, accidental, and preventable); each cluster entails different levels of reputational threat based on how publics perceive and attribute crisis responsibility to the organization (Coombs, 1998; Coombs \& Holladay, 1996, 2002). The publics attribute very little crisis responsibility in the victim cluster (e.g., natural disaster) and low crisis responsibility in the accidental cluster (e.g., technical-error accidents; Coombs, 2015). However, the publics attribute strong crisis responsibility in the preventable cluster (e.g., human-error accidents) (Coombs, 2006; Schwarz, 2012). Accordingly, crisis managers choose appropriate response strategies to not only frame the crisis type but also change publics' perception of the organization in crisis (Boin, Hart, \& McConnell, 2009; Ulmer et al., 2014). At the same time, the news media frame the crisis in similar or dissimilar ways (Bowen \& Zheng, 2015; Coombs, 2007b). Sometimes, crisis managers and publics may disagree on the crisis type. The publics tend to seek crisis information, perceive crisis responsibility, and change their view of reputation of the organization based on media coverage of the crisis, rather than crisis managers' strategies (Cho \& Gower, 2006; Holladay, 2009; Liu \& Kim, 2011). The publics attempt to reduce uncertainty at the beginning stage of a crisis by seeking news media information to gain a better understanding of the crisis (Spence, Westernman, Skalski, Seeger, Sellnow, \& Ulmer, 2006). The publics are more likely not only to accept crisis messages via news media than the messages via social media or word-of-mouth and more likely to provide supportive messages for the organization when the crisis information comes from journalists (Liu, Austin, \& Jin, 2011). Thus, the news media exert a major force on public discourse online in crisis situations, although the popularity of social media has been growing (Etter \& Vestergaard, 2015; Utz, Schultz, \& Glocka, 2013).

Nevertheless, the extant research has rarely illuminated the actual effects of crisis news framing on crisis outcomes, because it has focused on content analyses of crisis news coverage (e.g., An \& Gower, 2009; Bowen \& Zheng, 2015; Liu \& Kim, 2011; Van Der Meer, Verhoeven, Beentjes, \& Vliegenthart, 2014). Moreover, the previous research has heavily emphasized the relationship between various crisis types framed differently and crisis responsibility or attitudes (e.g., Cho \& Gower, 2006; Claeys \& Cauberghe, 2014; Coombs \& Holladay, 2001), not actual crisis outcomes such as reputation and behavioral intentions based on publics' perception (Coombs \& Holladay, 1996, 2007; Lee, 2005). Hence, it would be a more realistic approach to examine how crisis news framing directly influences the actual crisis outcomes. 
An organizational reputation is a perceptual construct that resides in publics' heads; that is, what the publics actually think, say, or evaluate about an organization (Coombs \& Holladay, 2007; Helm \& Tolsdorf, 2013; Kim, Hung-Baesecke, Yang, \& Grunig, 2013). Many scholars agree that a crisis is a threat to reputational assets (Gaultier-Gaillard \& Louisot, 2006; Jacques, 2014). In this sense, effective crisis communication is expected to help the organization repair and/or prevent reputational damage, as well as sometimes have a more positive reputation than it had before the crisis (Coombs, 2007b; Fearn-Banks, 2011; Ulmer et al., 2014; Van Der Meer, 2014). Moreover, a crisis leads the publics to be less likely to report supportive behavioral intentions such as saying nice things about the organization and using its products and services (Coombs, 2007b; Coombs \& Holladay, 2001, 2007; Siomkos \& Kurzbard, 1994). Thus, reputation and behavioral intention toward an organization are important outcomes in crisis communication.

In the crisis framing research, a recent crisis communication study demonstrates the direct relationship crisis types framed differently and the crisis outcomes by finding that preventable crises had the most negative effects on organizational reputation in a hypothetical crisis using fictitious company (Claeys et al., 2010). More recently, lannarino, Veil, and Cotton's (2015) study indicated that the news framing of the 2011 Japan nuclear crisis from US evening networks may have shaped publics' negative perception and not supportive behaviors toward nuclear development in the United States. To confirm the direct and strong relationship between crisis news framing and crisis outcomes in the actual crisis types helping to enhance ecological validity (Turk, Jin, Stewart, Kim, \& Hipple, 2012), this study proposes the following hypothesis:

H1: Preventable crisis news framing will be a stronger predictor for an organization's negative crisis outcomes, reputation, and behavioral intentions, than other news framing (accidental crisis news framing or no framing).

\section{Communicative action in problem solving (CAPS) in crisis situations}

As aforementioned, examining crisis news framing is in an effort to understand public's perception of a given crisis to effectively communicate with the publics of the organization (Kim \& Cameron, 2011; Kim et al., 2012a). To more effectively communicate, nonetheless, crisis managers need to identify and understand the key publics who are more likely to influence others by selecting (permit), transmitting (forward), and acquiring (seeking) crisis information than are other publics (e.g., passive publics; Ni \& Kim, 2009). Nonetheless, identifying and examining different publics' communicative behaviors in crisis situations have been rarely highlighted in crisis communication studies (Austin et al., 2012; Kim, Jung, Park, \& Dutta, 2009). Dominant crisis communication theories such as Coombs's (2007b) SCCT and Benoit's (1997) image repair theory do not consider different publics' communicative behaviors in crisis situations, ultimately influencing the organization's crisis communication (Austin et al., 2012; Olsson, 2014).

In public relations practice and research, identifying the publics' communicative behaviors and predicting impacts have received special attention for several decades (Kim \& Krishna, 2014). Grunig's $(\underline{1968}, 1997)$ Situational Theory of Publics (STP) was built to identify who publics are by explaining why and how they communicate. As an extended and generalized version of STP, Kim and Grunig (2011) proposed Situational Theory of Problem Solving (STOPS). STOPS explains why and how an individual communicates during problematic life situations based on a more comprehensive and theoretical 
framework, CAPS, which details communicative behaviors in problematic situations (Kim \& Krishna, 2014). The CAPS delineates communicative activeness in information taking, selecting, and giving in terms of active and passive components (Kim et al., 2010). CAPS conceptualizes communication behaviors in three domains, including information acquisition, selection, and transmission, thus leading to six communication behavioral variables: seeking (active) and attending (passive) in the information acquisition, forefending (active) and permitting (passive) in the information selection, and forwarding (active) and sharing (passive) in the information transmission (Kim et al., 2010).

The CAPS literature demonstrates that more active communicative behaviors have "most of the strategic potential" because such communicative actions can explain "how problematic situations (e.g., crises) arise and are shared and sustained" (Ni \& Kim, 2009, p. 220; Vasquez \& Taylor, 2001). The extant research has indicated that the active and aware publics actively transmit their dissatisfaction with the organization to inactive publics and tend to create a negative reputation (Kim et al., 2013; Kim $\&$ Rhee, 2012). The active publics share, forward, and discuss crisis messages via various media channels, including interpersonal, traditional, and social media (Utz et al., 2013). The communicative behaviors using social media (e.g., blogs and Facebook) can help the publics reduce uncertainty, maintain support, and achieve expressive and instrumental communication goals in crisis situations (Liu, Jin, \& Austin, 2013; Procopio \& Procopio, 2007). If the active publics become aware of the crisis from such media before the organization officially notifies them, it can cause tension in the relationship, resulting in negative outcomes in crisis communication (Coombs, 2015). Even in post-crisis situations, the active communicative actions (i.e., forefending, seeking, forwarding) play a critical role in the evolution or devolution of issues and conflicts (Kim, Kim, Tam, \& Kim, 2014; Ni \& Kim, 2009). Examining active publics' communicative actions for effective crisis communication can help crisis managers strategically learn where to go or how to communicate in a crisis situation (Coombs \& Holladay, 2014). To demonstrate the importance of active publics and their communicative behaviors and elaborate their empirical evidence on crisis outcomes, consequently, this study applied CAPS to a crisis situation. Therefore, this study posits the following hypothesis:

H2: Active communication actions, forefending, forwarding, and seeking of information, will be significant predictors for crisis outcomes, reputation and behavioral intentions, more than passive communication actions, permitting, sharing, and attending of information.

In the STP and STOPS literature, publics' enduring characteristics such as formal membership in a group, demographics, or psychographics are regarded as cross-situational (static) variables (Kim et al., 2008). The relevant studies have demonstrated that the cross-situational factors, especially demographics and socioeconomic status, have some effects on publics' communicative actions in problematic situations (Grunig, 1997; Kim et al., 2009; Kim, Ni, S.-H., \& Kim, 2012b). Hence, this study asks the following research question:

RQ1: Controlling for the effects of demographics, including age, education, gender, income, and race, are preventable crisis news framing and active communication actions still able to predict a significant amount of the variance in negative crisis outcomes, reputation and behavioral intentions? 


\section{Method}

For this study, an online experiment was conducted with the between-subjects groups randomly assigned, two different news framing groups and a control group. Because many scholars and practitioners agree that a real crisis is the best textbook for learning crisis communication (Coombs \& Holladay, 2001; Park \& Hon, 2010), an actual airline crash was used. The airline industry has recently become one of the most crisis-prone industries (ICM Crisis Report, 2013), and the airline crash has been frequently investigated in a number of crisis communication studies (Helm \& Tolsdorf, 2013; Lee, 2005). On July 6, 2013, Asiana Airlines (Seoul, South Korea based) Flight 214, with 307 people on board, crashed as it approached San Francisco International Airport. The incident killed three teen-aged girls from China and seriously injured 181 others (Karp, 2013). After investigating for almost a year, the National Transportation Safety Board concluded that the pilot's mismanagement caused the crash (ABC News, 2014). Actual news stories covering the crisis were adopted for this experiment.

\section{Participants}

The participants in this study were 1,113 people living in the United States. Excluding missing data $(N=40)$, the total sample was 1,073 . The ages ranged from 18 to 80 years old, with the average age of respondents at 35.8. Men accounted for 39.1\% $(N=420)$ and women were $60.9 \%(N=653)$. Among the participants, $75.1 \%(N=804)$ were White, 9.4\% $(N=100)$ were African American, $7.1 \%(N=76)$ were Asian American, and other races were 8.4\% ( $N=90)$. Participants in this study were recruited through an online web-based platform (Amazon.com's Mechanical Turk; M-Turk) with a diverse subject pool in October, 2013. M-Turk subjects were all volunteers paid 50 cents to complete the questionnaire. MTurk is a burgeoning and promising vehicle for experiment studies in social science, recruiting and paying participants to perform tasks (Berinsky, Huber, \& Lenz, 2012).

\section{Stimulus development}

To choose different news framing stories from a real crisis case, each representative story framing was chosen from national US newspapers (e.g., the New York Times, USA Today) published during one month after the crisis occurred, from the first day (July 6) to August 5. Three stories were selected based on (a) technical problems (accidental crisis framing), which can lead to low attribution of crisis responsibility; (b) pilot's performance error (preventable crisis framing), which can lead to strong attribution of crisis responsibility; and (c) no-framed story describing the crash without any framing. Each stimulus story was cut down to around 260 words to reduce the participants' fatigue.

\section{Procedure}

Participants were informed by the consent form about the purpose, procedures, statement of privacy, and benefits, and then asked to indicate their agreement with what they would do to answer after reading the crisis scenario and each crisis news article. In the experiment, this study had three conditions with a control group (i.e., no-framed news story group) and two experimental conditions based on two different news stories framed either with the pilot's performance error (preventable crisis) or a technical problem (accidental crisis) leading to the crash. Before the participants were exposed to the different news stories, they were briefly introduced to the crisis event through a press release from Asiana Airlines, which included simple factual information about the crash. The participants then answered questions measuring information forefending, permitting, forwarding, 
sharing, seeking, and attending as the independent variables. The participants were randomly assigned to one of the three conditions: no frame, preventable crisis, and accidental crisis news framing group. After random assignment, reputation and behavioral intentions toward the organization were measured as the crisis outcomes (dependent variables). The experiment questionnaire was created on Qualtrics.com, a web-based tool, and the link was launched on M-Turk. The participants could withdraw from the survey at any time.

\section{Measures}

Multiple items were used for each variable and measured on a 7-point bipolar Likert-type scale (1 = not at all to 7 = very much). To measure situational communication behavioral variables, this study adopted Kim and Grunig's (2011) STOPS scales consisting of five items measuring each variable. Participants answered the questions assessing whether they were active or passive in information acquisition, selection, and transmission: forefending (active in information acquisition; e.g., I know where to go when I need updated information regarding this crisis; Cronbach's $\alpha=0.76)$, permitting (passive in information acquisition; e.g., for this crisis, I welcome any information regardless of where it comes from; $\alpha=0.76$ ), forwarding (active in information transmission; e.g., if it is possible, I take time to explain this crisis to others; $\alpha=0.90$ ), sharing (passive in information transmission; e.g., I may not initiate but willing to have conversation about this crisis; $\alpha=0.88$ ), attending (passive in information selection; e.g., If I hear someone talking about this crisis, I am likely to listen; $\alpha=0.89$ ), and seeking (active in information selection; e.g., I am willing to contact people about this type of crisis to learn what kind of solutions there are; $\alpha=0.88$ ).

Regarding dependent variables, this study used SCCT scales (Coombs, 1998; Coombs \& Holladay, 1996). Crisis reputation was measured by five items (e.g., under most circumstance I would be likely to believe what the organization says; $\alpha=0.79$ ). Positive behavioral intentions were measured by four items (e.g., saying nice things about the organization to other people) collapsed to one item as well $(\alpha=0.87)$. In addition, participants were asked for demographic (age, gender, and race) and socioeconomic characteristics (income and education level).

\section{Results}

\section{Manipulation checks}

Each framing group was almost an equal sample size: accidental framing group $(N=361)$, preventable framing group ( $N=355)$, no framing group $(N=358)$, and demographic characteristics in each group were all balanced without any significant differences at $0.05(p>0.05)$. To check the news framing manipulation leading to the intended effect on crisis outcomes, participants were asked to rate the following items with a 7-point scale ( 1 = not at all, 7 = very much); "the cause of the crisis was something (accidental crisis) other circumstance or organizations could have controlled," and "the cause of the crisis was something the pilot's error (preventable crisis) could have controlled." The results of one-way ANOVA showed that manipulation of different news framing stories was successful. Participants who read an article framed by preventable crisis (pilot's error; $M=5.01, S D=1.26$ ) perceived significantly higher crisis responsibility on the pilot than those who read article framed by accidental crisis (technical problem; $M=4.27, S D=1.25)$, and no frame $(M=4.12, S D=1.06), F(2$, $1071)=56.55, p<0.001$. Post-hoc comparison using the Tukey Honestly Significant Difference (HSD) 
test revealed that the mean score of participants who read an article framed by the pilot's error was significantly higher than the means of those in other framing groups, technical problem and no framing $(p<0.05)$. In addition, participants reading an article framed by the technical problem $(M=4.21$, $S D=1.09)$ perceived significantly higher crisis responsibility on technical problem or Boeing than those reading article framed by pilot's error $(M=3.72, S D=1.32)$ and no framing $(M=4.03, S D=0.88), F(2$, $1071)=18.13, p<0.001$. Post-hoc comparison using the Tukey HSD test revealed that the mean score of participants who read an article framed by the technical problem was significantly higher than the means of those who read the news story framed by the pilot's error, not means in no-framed group $(p<0.05)$. Overall, the analyses demonstrated that participants perceived different crisis responsibility leading to crisis outcomes between conditions as intended.

News framing, communicative behaviors, and crisis outcomes

To test hypotheses, a series of multiple ordinary least squares (OLS) regression analyses were conducted in STATA 13 statistical software program. Assumptions were checked to ensure that there was no violation. In checking multicollinearity, there were a few high coefficients of pair-wise correlations among variables (i.e., above $r=0.80)$ : Asian and Black race $(r=0.92)$, Asian and Other race $(r=0.93)$, and Black and Other race $(r=0.92)$. However, the variance inflation factor (VIF) and tolerance showed that there was not a violation of multicollinearity in all independent variables (i.e., VIF of each variable $<10$ and tolerance of each variable $>0.10$ ). Regarding heteroskedasticity, BreuschPagan/Cook-Weisberg test was conducted and revealed that there was heteroskedasticity as fitted values of reputation, $\chi^{2}(1)=7.60, p<0.05$, and behavioral intention, $\chi^{2}(1)=31.06, p<0.05$, were smaller than 0.05 . For this reason, White's heteroskedastic robust standard error was run as a remedial measure, and this study reports the results (i.e., changed standard errors and tests of statistical significance).

To run multiple OLS regression analyses, framing factors were recoded as dichotomous variables, and accidental (accidental crisis: 1 , others: 0 ) and preventable (preventable crisis: 1 , others: 0 ) crisis news framing variables were included in the models. Regarding CAPS variables (information forefending, permitting, forwarding, sharing, seeking, and attending), confirmatory factor analysis (CFA) using AMOS 22 was run to check the dimensionality of the measures and the covariance of items (i.e., composite reliability and construct validity). The initial CFA revealed that there was a measurement item for information forefending in a violation of construct validity due to significantly low level standardized loading $(\beta<0.50)$ and average variance extracted (AVE $<0.50)$ (Hair, Black, Babin, \& Anderson, 2009). The item was deleted, and CFA was then run again. Construct validity (standardized loading estimate $>0.50$, convergent validity: AVE $>0.50$, discriminant validity: AVE $>$ average shared varience), and composite reliability (CR $>0.70$ ) were successfully established in all measurement items (Hair et al., 2009). The CFA model goodness-of-fit indices also met all of the joint criteria by Hu and Bentler (1999): $\chi^{2}(231, N=1,074)=687.532, \chi^{2} / d f=2.98, p=0.00$, Comparative Fit Index $(\mathrm{CFI})=0.98$, Standardized Root Mean Square Residual $(S R M R)=0.04$, Root Mean Square Error of Approximation $($ RMSEA $)=0.05$ (See Table 1) 
Table 1. Composite reliability and construct validity of CAPS $(N=1,074)$.

\begin{tabular}{|c|c|c|c|c|c|c|}
\hline $\begin{array}{l}\text { Latent } \\
\text { variable }\end{array}$ & Measurement items & $\begin{array}{l}\text { Standardized } \\
\text { loading estimate } \\
(\beta)\end{array}$ & $\begin{array}{l}\text { Explained } \\
\text { variance }\left(R^{2}\right)\end{array}$ & $\begin{array}{l}\text { Composite } \\
\text { reliability (CR) }\end{array}$ & $\begin{array}{l}\text { Average } \\
\text { variance } \\
\text { extracted (AVE) }\end{array}$ & $\begin{array}{l}\text { Average } \\
\text { shared } \\
\text { variance (ASV) }\end{array}$ \\
\hline \multirow{4}{*}{$\begin{array}{l}\text { Information } \\
\text { forefending } \\
\text { (IFF) }\end{array}$} & $\begin{array}{l}\text { Others respect my perspective about this crisis } \\
\text { because it is simple and clear. }\end{array}$ & 0.72 & 0.61 & 0.78 & 0.55 & 0.43 \\
\hline & $\begin{array}{l}\text { I know where to go when I need updated } \\
\text { information regarding this crisis. }\end{array}$ & 0.50 & 0.43 & & & \\
\hline & $\begin{array}{l}\text { I feel like resisting some persuasive efforts about this } \\
\text { crisis. }\end{array}$ & 0.66 & 0.24 & & & \\
\hline & $\begin{array}{l}\text { I express my opinions confidently about what should } \\
\text { be done to deal with this crisis. }\end{array}$ & 0.78 & 0.60 & & & \\
\hline \multirow[t]{5}{*}{$\begin{array}{l}\text { Information } \\
\text { permitting } \\
\text { (IPM) }\end{array}$} & $\begin{array}{l}\text { To make better decisions regarding this crisis, I listen } \\
\text { to views and information opposite to my own as long } \\
\text { as they are related to the crisis. }\end{array}$ & 0.85 & 0.44 & 0.81 & 0.53 & 0.30 \\
\hline & $\begin{array}{l}\text { For this crisis, I welcome any information regardless } \\
\text { of where it comes from. }\end{array}$ & 0.72 & 0.43 & & & \\
\hline & $\begin{array}{l}\text { I am careful in accepting information about this crisis } \\
\text { because of the hidden interests of those who } \\
\text { provide the information. }\end{array}$ & 0.50 & 0.29 & & & \\
\hline & I listen even to opposite views on this crisis. & 0.66 & 0.52 & & & \\
\hline & $\begin{array}{l}\text { At times, I find that I have accepted conflicting } \\
\text { information about this type of crisis. }\end{array}$ & 0.67 & 0.72 & & & \\
\hline \multirow{5}{*}{$\begin{array}{l}\text { Information } \\
\text { forwarding } \\
\text { (IFW) }\end{array}$} & $\begin{array}{l}\text { If possible, I will take the time to explain this crisis to } \\
\text { others. }\end{array}$ & 0.84 & 0.52 & 0.90 & 0.65 & 0.53 \\
\hline & $\begin{array}{l}\text { It is worth spending some time to persuade others } \\
\text { about this crisis. }\end{array}$ & 0.76 & 0.72 & & & \\
\hline & $\begin{array}{l}\text { I look for chances to share my knowledge and } \\
\text { thoughts about this crisis. }\end{array}$ & 0.86 & 0.73 & & & \\
\hline & $\begin{array}{l}\text { I actively seek out opportunities to participate in } \\
\text { public opinion polls about this crisis. }\end{array}$ & 0.85 & 0.58 & & & \\
\hline & $\begin{array}{l}\text { I love to start a conversation on this crisis with } \\
\text { others. }\end{array}$ & 0.72 & 0.70 & & & \\
\hline \multirow[t]{2}{*}{$\begin{array}{l}\text { Information } \\
\text { sharing (ISH) }\end{array}$} & $\begin{array}{l}\text { I may not initiate but willing to have conversation } \\
\text { about this crisis. }\end{array}$ & 0.77 & 0.56 & 0.88 & 0.59 & 0.48 \\
\hline & $\begin{array}{l}\text { I talk about this type of crisis when others bring up } \\
\text { the topic. }\end{array}$ & 0.83 & 0.66 & & & \\
\hline
\end{tabular}




\begin{tabular}{|c|c|c|c|c|c|c|}
\hline & $\begin{array}{l}\text { I am willing to participate in casual conversations } \\
\text { about this crisis. }\end{array}$ & 0.66 & 0.44 & & & \\
\hline & $\begin{array}{l}\text { I would join in a conversation when I hear people } \\
\text { talking about this crisis. }\end{array}$ & 0.81 & 0.68 & & & \\
\hline & $\begin{array}{l}\text { I am sure that I will be quite active in passing on } \\
\text { information related to this crisis in the near future. }\end{array}$ & 0.75 & 0.60 & & & \\
\hline \multirow[t]{5}{*}{$\begin{array}{l}\text { Information } \\
\text { seeking (ISK) }\end{array}$} & $\begin{array}{l}\text { I am willing to contact people about this type of crisis } \\
\text { to learn what kind of solutions there are. }\end{array}$ & 0.83 & 0.73 & 0.87 & 0.58 & 0.51 \\
\hline & I am willing to visit Web sites relevant to this crisis. & 0.67 & 0.61 & & & \\
\hline & $\begin{array}{l}\text { I am willing to check to see if there is any new } \\
\text { information about this crisis on the Internet. }\end{array}$ & 0.65 & 0.42 & & & \\
\hline & $\begin{array}{l}\text { I would request booklets containing relevant } \\
\text { information about this crisis. }\end{array}$ & 0.78 & 0.45 & & & \\
\hline & I actively search for information on this topic. & 0.86 & 0.69 & & & \\
\hline \multirow{5}{*}{$\begin{array}{l}\text { Information } \\
\text { attending } \\
\text { (IAT) }\end{array}$} & $\begin{array}{l}\text { If I hear someone talking about this crisis, I am likely } \\
\text { to listen. }\end{array}$ & 0.76 & 0.68 & 0.90 & 0.65 & 0.42 \\
\hline & I attend to news when they cover this crisis. & 0.79 & 0.79 & & & \\
\hline & $\begin{array}{l}\text { I paid attention to a news report about this kind of } \\
\text { crisis recently. }\end{array}$ & 0.75 & 0.57 & & & \\
\hline & $\begin{array}{l}\text { I pay attention to this crisis when a news report } \\
\text { appears on TV news. }\end{array}$ & 0.89 & 0.62 & & & \\
\hline & $\begin{array}{l}\text { I may take some time to listen if someone tries to } \\
\text { give information about this crisis. }\end{array}$ & 0.83 & 0.57 & & & \\
\hline
\end{tabular}

Note. Construct validity (standardized loading estimate $>.50$, convergent validity: AVE > .50, discriminant validity: AVE > ASV), and composite reliability (CR > .70) were successfully established (Hair et al., 2009). CAPS Confimatory Factor Analysis (CFA) model goodness-of-fit indices met all of the joint criteria by Hu and Bentler (1999): $\chi^{2}(231, N=1,074)=687.532, \chi^{2} / d f$ ratio $=2.98, p=.00$, Comparative Fit Index $($ CFI) $=.98$, Standardized Root Mean Square Residual $(S R M R)=.04$, Root Mean Square Error of Approximation (RMSEA) $=.05$. 
Together, all independent variables (CAPS: information forefending, permitting, forwarding, sharing, seeking, and attending and framing: accidental and preventable) in the model accounted for a significant portion of the variance in reputation, $R^{2}=0.06, F(8,1074)=8.62, p<0.001$ and behavioral intention, $R^{2}=0.19, F(8,1073)=22.09, p<0.001$. H1 proposed that preventable crisis news framing will be a stronger predictor for an organization's negative crisis outcomes, reputation, and behavioral intentions, than accidental news framing and no framing. As expected, preventable crisis news framing appeared as a strong predictor for negative crisis outcomes. The results indicated that one unit change in preventable crisis news framing results in a decrease of 0.36 in the organization's reputation $(b=-0.36, t=-4.44)$ and a decrease of 0.23 in positive behavioral intentions $(b=-0.23, t=-2.50)$, controlling for effects of other independent variables in the models (See Table 2).

Table 2. OLS regression analyses for the relationship between CAPS and crisis outcomes.

\begin{tabular}{|c|c|c|c|c|}
\hline Variables & $\begin{array}{l}\text { Reputation } \\
\text { (RT) }\end{array}$ & & $\begin{array}{l}\text { Behavioral intentions } \\
\text { (BI) }\end{array}$ & \\
\hline & $\mathrm{b}$ & $\mathrm{t}$ & $\mathrm{b}$ & $\mathrm{t}$ \\
\hline \multicolumn{5}{|l|}{ Step 1} \\
\hline Constant & 4.61 & $33.58 * * *$ & 1.92 & $11.70 * * *$ \\
\hline Forefending (active selection) & -0.04 & -1.00 & 0.07 & 1.48 \\
\hline Permitting (passive selection) & 0.05 & 1.34 & -0.08 & -1.82 \\
\hline $\begin{array}{l}\text { Forwarding (active } \\
\text { transmission) }\end{array}$ & -0.09 & -1.92 & 0.30 & $6.29 * * *$ \\
\hline Sharing (passive transmission) & -0.07 & -1.65 & -0.13 & $-2.33^{*}$ \\
\hline Seeking (active acquisition) & -0.04 & -1.00 & 0.20 & $3.93 * * *$ \\
\hline Attending (passive acquisition) & 0.18 & $4.77 * * *$ & -0.01 & -0.15 \\
\hline Accidental crisis news framing & -0.07 & -0.95 & -0.04 & -0.46 \\
\hline Preventable crisis news framing & -0.36 & $-4.44 * * *$ & -0.23 & $-2.50 *$ \\
\hline$N$ & 1,074 & & 1,073 & \\
\hline$R^{2}$ & 0.06 & & 0.19 & \\
\hline$F$ & $8.62 * * *$ & & $22.09 * * *$ & \\
\hline \multicolumn{5}{|l|}{ Step 2} \\
\hline Constant & 4.36 & $21.64 * * *$ & 2.62 & $10.69 * * *$ \\
\hline Forefending (active selection) & -0.04 & -0.97 & 0.05 & 1.13 \\
\hline Permitting (passive selection) & 0.04 & 1.21 & -0.08 & -1.90 \\
\hline $\begin{array}{l}\text { Forwarding (active } \\
\text { transmission) }\end{array}$ & -0.08 & -1.75 & 0.28 & $5.84 * * *$ \\
\hline Sharing (passive transmission) & -0.06 & -1.41 & -0.10 & $-2.03 *$ \\
\hline Seeking (active acquisition) & -0.04 & -0.83 & 0.20 & $4.09 * * *$ \\
\hline Attending (passive acquisition) & 0.16 & $4.10 * * *$ & -0.00 & -0.11 \\
\hline Accidental crisis news framing & -0.08 & -1.06 & -0.03 & -0.35 \\
\hline Preventable crisis news framing & -0.37 & $-4.50 * * *$ & -0.24 & $-2.61 * *$ \\
\hline Age & 0.01 & $2.00 *$ & -0.01 & $-2.00 *$ \\
\hline Gender & 0.10 & 1.46 & -0.11 & -1.44 \\
\hline Education & 0.02 & 0.81 & -0.08 & $-3.06 * *$ \\
\hline Income & -0.01 & -0.78 & -0.00 & -0.09 \\
\hline Asian race & 0.01 & 0.13 & 0.10 & 0.78 \\
\hline
\end{tabular}




\begin{tabular}{|l|r|r|r|r|}
\hline Black race & 0.01 & 0.13 & 0.03 & 0.30 \\
\hline Other race & -0.08 & -0.90 & -0.10 & -0.44 \\
\hline$N$ & 1,070 & & 1,070 & \\
\hline$\Delta R^{2}$ & 0.01 & & 0.02 & \\
\hline$R^{2}$ & 0.07 & & 0.21 & \\
\hline$F$ & $6.55^{* * *}$ & & $15.93^{* * *}$ & \\
\hline
\end{tabular}

Note. ${ }^{* * *} p<0.001,{ }^{* *} p<0.01,{ }^{*} p<0.05$. Results were based on White's heteroskedastic robust standard errors because the Breusch-Pagan/Cook-Weisberg test revealed that there was heteroskadesticity (RT: $\left.\chi^{2}(1)=7.89, p<0.05, \mathrm{BI}: \chi^{2}(1)=30.40, p<0.05\right)$. Independent variables were not in a violation of multicollinearity (i.e., VIF of each variable $<10$ and Tolerance of each variable $>0.10$ ).

To estimate how different effects the preventable crisis framing compared to other framing factors have on crisis outcomes, reputation and supportive behavioral intentions, coefficients of all independent variable were applied to the multiple regression equation, $Y=a+b_{1} * X_{1}+b_{2} * X_{2}+\ldots+$ $b_{p}{ }^{*} X_{p}$ (e.g., Predicted value of preventable crisis framing on RT $\left[\hat{Y}_{\text {preventable-reputation }}\right]=4.36+$ $[-0.04]^{*}$ forefending...[-0.37]*[1: preventable crisis new framing $]+[-0.08] *[0$ : accidental crisis news framing]...+ [-0.08]* Other race). As a result, the predicted value of preventable crisis news framing ( $\hat{Y}_{\text {preventable-reputation }}$ ) on reputation was 0.37 lower than no-framing ( $\left.\hat{Y}_{\text {no-reputation}}\right)$ and 0.39 lower than accidental crisis news framing ( $\left.\hat{Y}_{\text {accidental-reputation }}\right)$; there was a small amount difference $(0.08)$ between $\hat{Y}_{\text {no-reputation }}$ and $\hat{Y}_{\text {accidental-reputation. Regarding supportive behavioral intentions, the predicted value of }}$ preventable crisis news framing ( $\left(\hat{Y}_{\text {preventable-behavioral }}\right)$ was 0.24 lower than no-framing $\left(\hat{Y}_{\text {no-behavioral }}\right)$ and 0.21 lower than accidental crisis news framing ( $\left.\hat{Y}_{\text {accidental-behavioral }}\right)$. However, there was 0.03 difference

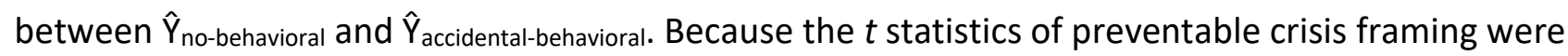
-4.50 (reputation) and -2.61 (supportive behavioral intentions), the differences of predicted values were statistically significant. Therefore, $\mathrm{H} 1$ is supported.

Inconsistent with $\mathrm{H} 2$, all active communication actions, forefending, forwarding, and seeking of information, were not significant predictors for crisis outcomes, but there were different communication actions present as strong predictors for reputation and behavioral intentions. In reputation, only one communicative behavior variable, attending ( $b=0.18, t=4.77$ ), was found as a strong predictor. This result reveals that every one unit change of passive acquisition (attending) results in an increase of 0.18 in the organization's reputation, controlling for effects of other independent variables in the model (Step 1). When it comes to positive behavioral intentions, active information transmission (forwarding; $b=0.30, t=6.29$ ) and acquisition (seeking; $b=0.20, t=3.93$ ) were positively associated, but a passive communicative behavior (information transmission: sharing) appeared as a negative predictor ( $b=-0.13, t=-2.23)$, controlling for effects of other independent variables in the model (Step 1). Consequently, $\mathrm{H} 2$ is partially supported (See Table 2).

To answer RQ1, demographic and socioeconomic variables (age, education, gender, income, and race) were added into the regression models (Step 2). Gender (female $=1$, male $=0$ ) and race (Asian, Black, and Other race: non-White but also non-Asian and non-Black) were recoded as dichotomous variables. Independent variables (two framing variables, six communication actions, and five demographic and socioeconomic factors) in the model accounted for a significant portion of the variance in reputation, $R^{2}=0.07, F(15,1070)=6.55, p<0.001$ and behavioral intention, $R^{2}=0.21, F(15,1070)=15.93$, 
$p<0.001$ (Step 2). There was the increase of $1 \%$ (reputation: $\Delta R^{2}=0.01$ ) and $2 \%$ (behavioral intention: $\Delta R^{2}=0.02$ ) in variance from previous models (Step1). Controlling for effects of other independent variables in the models, information attending $(b=0.16, t=4.10)$ and preventable crisis news framing $(b=-0.37, t=-4.50)$ were still able to strongly predict the organization's reputation, and the effects of information forwarding $(b=0.29, t=6.26)$, seeking $(b=0.20, t=4.18)$, sharing $(b=-0.10, t=-2.03)$ and preventable crisis news framing $(b=-0.24, t=-2.61)$ were consistent as significant predictors for behavioral intentions as well. Among demographic variables, age was a positive predictor $(b=0.01$, $t=2.00)$ for reputation as well as a negative predictor $(b=-0.01, t=-2.08)$ for behavioral intentions. Education ( $b=-0.08, t=-3.06$ ) was negatively associated with only behavioral intentions when controlling for the effect of other independent variables (See Table 2).

\section{Discussion}

\section{Understanding publics' perception through the framing effect}

As $\mathrm{H} 1$ anticipated, this study found that preventable crisis news framing was a strong negative predictor for an organization's crisis outcomes, controlling for the effect of other variables and communicative behaviors, as well as demographic and socioeconomic characteristics. This result corroborates the most negative effect of preventable crisis type on reputation of the organization and publics' behavioral intentions because the preventable crises produce strong attribution of crisis responsibility. In addition, the effect of accidental crisis news framing was not statistically significant compared to no-framing news, although it appeared a negative predictor for crisis outcomes. Such different magnitudes of preventable and accidental news framing on the crisis outcomes underpin the relationship crisis types and level of crisis responsibility. Thus, this study supports the SCCT research that accidental crisis types produce low attribution of crisis responsibility and preventable crises lead to strong attribution of crisis responsibility. In turn, different crisis types lead crisis managers to choose different crisis response strategies as more defensive strategies (e.g., attacking the accuser) for accidental crises and more accommodative strategies (e.g., apology) for preventable crises to change publics' perceptions of the crisis or of the organization (Coombs, 1998, 2007b; Schwarz, 2012). The finding provides the actual and direct evidence demonstrating how news framing is an influential factor in crisis communication as the final arbitrator of publics' perception and interpretation of a crisis, thereby leading to reputational threat and negative behavioral intentions toward the organization.

Applying it to the crisis case of this study, crisis managers in Asiana Airlines may have had to monitor the media coverage to determine a crisis type the publics were likely to perceive, rather than focus on their own framing of the crisis. Even if public relations practitioners in the organization put more effort into framing the crash crisis as an accidental crisis (e.g., technical problem caused by Boeing) and making their defensive crisis response strategies (e.g., attacking the accuser or justification), their efforts and strategies may not have been successful for the publics who read more frequently news stories framing the crash crisis as a preventable crisis (e.g., pilot's error), expecting the organization's accommodative response strategies (e.g., apology or compensation). Thus, it is advisable that crisis communicators should take media coverage of a crisis into consideration when collecting, processing, and disseminating information required to address a crisis situation (i.e., crisis communication) (Coombs, 2015; Etter \& Vestergaard, 2015). In doing so, the crisis managers can choose appropriate 
crisis strategies for more effective crisis communication which helps better understand publics' perception, thereby restoring the organization's reputation and improving positive behavioral intentions toward the organization.

\section{Predicting and understanding publics' crisis communication behaviors through CAPS}

With regard to the organization's reputation in a crisis situation, attending (passive acquisition) was a significant predictor, controlling for the effects of other communicative behaviors. When demographic and socioeconomic characteristics were included in the model, the effect of information attending was consistent as a positively significant predictor for reputation. This result provides empirical evidence of the important effect of communicative action (information attending) on crisis outcomes, although it was an unexpected finding. Information attending refers to less-active communicative behaviors characterized by "unplanned discovery of a message followed by continued processing of it" (i.e., unintentional discovery of information) (Clarke \& Kline, 1974; Kim et al., 2010, p. 132). Information attending reflects that the publics are less likely to feel the need to acquire information about the problem because they are likely to perceive a situation to be less problematic than perceived by others who have active information acquisition (i.e., information seeking publics) (Kim, 2006).

In addition, the publics who have information attending have built a solution and successfully tested it, and they do not need further information because they feel to have competence of the information (Kim et al., 2010). Hence, the publics in attending crisis information tend to be "passive and reactive in gaining only information that is easily available and accessible" (Kim et al., 2010, p. 130). Further, the information-attending publics are associated with "a chronic or dormant approach" because they are not engaged in information seeking but mostly processing the information (Ni \& Kim, 2009, p. 237). That is, they no longer seek additional information but only rely on updates available from the mass media in a problematic situation (Kim et al., 2014). In this sense, the findings of this study indicate the importance of immediate response, as well as accurate information in crisis communication to reduce the publics' uncertainty in a crisis (Coombs, 2015; Seeger \& Ulmer, 2001). Accordingly, crisis managers should attempt to make crisis information available and accessible to publics in order to increase information attending in a positive way, leading to protecting or restoring their organization's reputation.

Furthermore, the positive relationship between information attending and reputation in crisis situation can be supported by the importance of prior reputation for effective crisis communication. The finding implies that those who have information attending are likely to ignore the crisis if it contradicts the relevant information to the solution when the information-attending publics had a positive reputation previously. Thus, the positive relationship between information attending and reputation supports the positive effect of prior reputation on crisis outcomes as "a reservoir of good will" or "buffers" sustaining the organization in crisis situations (Helm \& Tolsdorf, 2013, p. 145; Tucker \& Melewar, $\underline{2005})$. As Coombs and Holladay (2001, p. 324) explained, the "deflective power of reputation in times of crisis," a previous reputation makes the publics interpret the crisis as an exceptional situation that can be disregarded. Based on the prior reputation, information-attending publics perceive the crisis as a less serious situation and they do not feel the need to acquire information. That is, they disregard the crisis information and keep maintaining their positive view of the reputation on the organization. Therefore, information attending empirically explains the importance of publics' previous information 
and organizational reputation perceived by the publics, helping shield the organization from reputational threat.

In behavioral intentions, more active information behavioral variables, transmission (forwarding) and acquisition (seeking), were positively significant, controlling the effects of other variables. According to the CAPS literature, the publics who engage in information forwarding and seeking are classified as activist publics who are more situational and active than other active publics (Kim, 2006; Kim et al., 2010; Ni \& Kim, 2009). In particular, information seeking is active communication behaviors that are more likely to initiate the collecting of information proactively because they feel an urge to deal with a problematic situation ( $\mathrm{Ni} \& \mathrm{Kim}, 2009$ ). Information transmission allows publics to mobilize resources to resolve the problem and evolve into a social collectivity from the isolated problem solvers by giving information of problems and solutions to others (Kim et al., 2010). For this reason, information transmission is "at the heart of the locating and networking with other individual problem solvers" because transmitting information about a problematic situation makes a problem produce a group of collective problem solvers (i.e., an activist group) (Kim, 2006, p. 297).

In this regard, the result of this study helps identify activist groups and explains why crisis managers primarily communicate with them as the key publics in crisis situations. The OLS regression results revealed that one unit changes of information forwarding and seeking results in increases of $28 \%$ and $20 \%$ in positive behavioral intentions toward the organization respectively. The activist publics who are actively acquiring (seeking) and transmitting (forwarding) are more likely to say nice thing about the organization to other people or show public support for the organization in crisis than other types of publics (Coombs, 2007b). Accordingly, the result indicates that crisis managers should identify the activist groups' communicative characteristics and strategically communicate with them for effective crisis communication, improving positive behavioral intentions toward their organization in crisis situations.

However, it is noteworthy that information sharing (passive transmission) was consistently negative for supportive behavioral intentions controlling for the effect of others. This result demonstrates how important information transmission plays a critical role in crisis communication even if it is passive or reactive. The findings also indicate the extent of activeness of communicative actions in crisis situations that distinguish forwarding and sharing could result in different effects on supportive behavioral intentions toward an organization. Even though the reactive transmitters (i.e., information sharers) are less likely to initiate their information giving themselves, their communicative actions are more likely to engage in negative word-of-mouth. Nonetheless, there should be more research to bear out the different effects based on activeness of information transmission. Because the information sharers are formerly active problem solvers who have acquired knowledge from past crisis situations (Kim et al., 2010), the finding in this study could be attributed to prior reputation or experience with the organization.

\section{Implications}

In terms of more realistic crisis communication practice, the results can direct and advise crisis managers as to how to conduct effective crisis communication when crisis type is ambiguous due to the uncertainty of the causality. In the real world, an accident produces greater variance in publics' perceptions. To determine the crisis type, the publics should "look to see what cues are present and 
being used to describe the crisis" (Coombs, 2015, p. 157). The publics not only rely on the media reports for crisis information, but also evaluate the cause of the crisis and the organization's responsibility based on the media coverage. For this reason, the publics have a different crisis type from what the crisis managers intend to frame in a crisis situation. If this is the case, the crisis managers should seriously consider adopting the publics' frame based on media coverage of the crisis and choosing appropriate crisis response strategies according the media framing. In this sense, this study bears out the importance of media framing effects in crisis communication, providing crisis managers with a useful direction for more effective crisis response strategies.

As a theoretical implication, this study provides a more comprehensive look into understanding the role of media shaping publics' perceptions of a crisis and the effects of publics' communicative actions on crisis outcomes. The findings indicate how the crisis communication researchers make theoretical efforts to fill the gap of current crisis communication theories, which do not consider different publics but focus on organizational reputation and blame avoidance strategies (Olsson, 2014). The researchers should "move beyond predominantly focusing on image management" (Liu \& Fraustino, 2014, p. 545). Understanding publics' perceptions and communicative actions in crisis situations is necessary to help the publics best cope and move forward after crises to manage a crisis as an opportunity for renewal (i.e., resilience-generating crisis communication theory; Ulmer et al., 2014). In other words, this study contributes to the theoretical development of crisis communication by providing empirical evidence of the need for a resilience-generating theory for effective crisis communication (Liu \& Fraustino, 2014; Olsson, 2014; Ulmer et al., 2014).

\section{Limitations and future research}

Despite the important findings and implications, this study has certain limitations. First, this study used an actual crisis case, and it is possible that participants were exposed to the crisis and crisis communication of the organization via diverse media prior to participation in the study (Utz et al., 2013). Moreover, other variables, especially emotions, prior reputation and relationship, were not considered in this study, even though those factors influence crisis outcomes such as reputation and behavioral intentions (Turk et al., 2012). Omitting those variables may have resulted in low values of $\mathrm{R}^{2}$ in the reputation variable. Compared to the other dependent variable, behavioral intentions ( $19 \%$ and $21 \%), R^{2}$ values of the reputation variable, the proportion of the variance explained by the factors such as CAPS, news framing, and demographics, were relatively lowered, $6 \%$ and $7 \%$. Even though this study makes a step forward in the theoretical efforts of crisis communication research, a majority of proportion of unexplained variance may lead public relations practitioners or crisis managers to cast doubt on the generalizability of results. To extend this study and find more generalizable results, future research should control for the prior exposure to news on the crisis and examine the relationship crisis outcomes with such influential factors, including organization's reputation and relationship. Finally, this study did not include other situational variables such as situational antecedents, perceptual and cognitive variables, and situational motivations which lead to CAPS (Kim \& Grunig, 2011). Understanding publics' perceptual variables (problem recognition, involvement recognition, and constraint recognition), cognitive variable (referent criterion), and motivation will help enhance theoretical power and utility as well as comprehensively predict publics' communicative behaviors in acquiring, selecting, and transmitting crisis information. 


\section{REFERENCES}

ABC NEWS. (2014, June 24). Pilot confusion caused fatal 2013 Asiana Airlines crash. Retrieved from http://abcnews.go.com/US/pilot-confusion-caused-fatal-2013-asiana-airlinescrash/story?id=24277662

An, S.K., \& Gower, K. K. (2009). How do the news media frame crises? A content analysis of crisis news coverage. Public Relations Review, 35, 107-112. doi:10.1016/j.pubrev.2009.01.010

Austin, L., Liu, B. R., \& Jin, Y. (2012). How audiences seek out crisis information: Exploring the socialmediated crisis communication model. Journal of Applied Communication Research, 40, 188207. doi:10.1080/00909882.2012.654498

Benoit, W. L. (1997). Image repair discourse and crisis communication. Public Relations Review, 23, 177-186. doi:10.1016/S0363-8111(97)90023-0

Berinsky, A. J., Huber, G. A., \& Lenz, G. S. (2012). Evaluating online labor markets for experimental research: Amazon.com's mechanical Turk. Political Analysis, 20, 351-368. doi:10.1093/pan/mpr057

Boin, A., Hart, P., \& McConnell, A. (2009). Crisis exploitation: Political and policy impacts of framing contests. Journal of European Public Policy, 16, 81-106. doi:10.1080/13501760802453221

Bowen, S. A., \& Zheng, Y. (2015). Auto recall crisis, framing, and ethical response: Toyota's missteps. Public Relations Review, 41, 40-49. doi:10.1016/j.pubrev.2014.10.017

Cho, S. H., \& Gower, K. K. (2006). Framing effect on the public's response to crisis: Human interest frame and crisis type influencing responsibility and blame. Public Relations Review, 32, 420422. doi:10.1016/j.pubrev.2006.09.011

Choi, J., \& Chung, W. (2013). Analysis of the interactive relationship between apology and product involvement in crisis communication: An experimental study on the Toyota recall crisis. Journal of Business and Technical Communication, 27, 3-31. doi:10.1177/1050651912458923

Claesys, A.-S., \& Cauberghe, V. (2014). What makes crisis response strategies work? The impact of crisis involvement and message framing. Journal of Business Research, 67, 182-189. doi:10.1016/j.jbusres.2012.10.005

Claeys, A., Cauberghe, V., \& Vyncke, P. (2010). Restoring reputations in times of crisis: An experimental study of the situational crisis communication theory and the moderating effects of locus of control. Public Relations Review, 36, 256-262. doi:10.1016/j.pubrev.2010.05.004

Clarke, P., \& Kline, F. G. (1974). Mass media effects reconsidered: Some new strategies for communication research. Communication Research, 1, 224-240. doi:10.1177/009365027400100205

Coombs, W. T. (1998). An analytic framework for crisis situations: Better responses from a better understanding of the situation. Journal of Public Relations Research, 10, 177-191. doi:10.1207/s1532754xjprr1003_02

Coombs, W. T. (2006). The protective powers of crisis response strategies: Managing reputational assets during a crisis. Journal of Promotion Management, 12, 241-260. doi:10.1300/J057v12n03_13

Coombs, W. T. (2007a). Attribution theory as a guide for post-crisis communication research. Public Relations Review, 33, 135-139. doi:10.1016/j.pubrev.2006.11.016

Coombs, W. T. (2007b). Protecting organization reputation during a crisis: The development and application of situational crisis communication theory. Corporate Reputation Review, 10, 163176. doi:10.1057/palgrave.crr.1550049

Coombs, W. T. (2009). Conceptualizing crisis communication. In R. L. Heath, \& H. D. O'Hair (Eds.), Handbook of risk and crisis communication (pp. 99-118). New York, NY: Routledge. 
Coombs, W. T. (2012). Parameters for crisis communication. In W. T. Coombs, \& S. J. Holladay (Eds.), The handbook of crisis communication (pp. 17-53). New York, NY: Wiley-Blackwell.

Coombs, W. T. (2015). Ongoing crisis communication: Planning, managing, and responding (4th ed.). Thousand Oaks, CA: SAGE.

Coombs, W. T., \& Holladay, S. J. (1996). Communication and attributions in a crisis: An experimental study in crisis communication. Journal of Public Relations Research, 8, 279-295. doi:10.1207/s1532754xjprr0804_04

Coombs, W. T., \& Holladay, S. J. (2001). An extended examination of the crisis situations: A fusion of the relational management and symbolic approaches. Journal of Public Relations Research, 13, 321-340. doi:10.1207/S1532754XJPRR1304_03

Coombs, W. T., \& Holladay, S. J. (2002). Helping crisis managers protect reputational assets: Initial tests of the situational crisis communication theory. Management Communication Quarterly, 16, 165-186. doi:10.1177/089331802237233

Coombs, W. T., \& Holladay, S. J. (2007). The negative communication dynamic: Exploring the impact of stakeholder affect on behavioral intention. Journal of Communication Management, 11, 300312.

Coombs, W. T., \& Holladay, S. J. (2008). Comparing apology to equivalent crisis response strategies: Clarifying apology's role and value in crisis communication. Public Relations, 34, 252-257. doi:10.1016/j.pubrev.2008.04.001

Coombs, W. T., \& Holladay, S. J. (2014). How publics react to crisis communication efforts: Comparing crisis response reactions across sub-arenas. Journal of Communication Management, 18, 40-57. doi:10.1108/JCOM-03-2013-0015

Dowling, G. (2002). Creating corporate reputations: Identity, image, and performance. New York, NY: Oxford University Press.

Etter, M. A., \& Vestergaard, A. (2015). Facebook and the public framing of a corporate crisis. Corporate Communication: An International Journal, 20, 163-177. doi:10.1108/CCIJ-10-2013-0082

Fearn-Banks, K. (2011). Crisis communication: A casebook approach (4th ed.). New York, NY: Routledge.

Gaultier-Gailard, S., \& Louisot, J. (2006). Risks to reputation: A global approach. The Genova Papers, 31, 425-445.

Grunig, J. E. (1968). Information, entrepreneurship, and economic development: A study of the decision making process of Colombian Latifundistas. Unpublished doctoral dissertation, University of Wisconsin.

Grunig, J. E. (1997). A situational theory of publics: Conceptual history, recent challenges and new research. In D. Moss, T. MacManus, \& D. Verčič (Eds.), Public relations research: An international perspective (pp. 3-46). London, U. K.: International Thompson Business Press.

Hair, J. F., Black, W. C., Babin, B. J., \& Anderson, R. E. (2009). Multivariate data analysis (7th ed.). Upper Saddle River, NJ: Prentice Hall.

Helm, S., \& Tolsdorf, J. (2013). How does corporate reputation affect customer loyalty in a corporate crisis? Journal of Contingencies and Crisis Management, 21, 144-152. doi:10.1111/14685973.12020

Holladay, S. J. (2009). Crisis communication strategies in the media coverage of chemical accidents. Journal of Public Relations Research, 21, 208-217. doi:10.1080/10627260802557548

Hu, L., \& Bentler, P. M. (1999). Cutoff criteria for fit indexes in covariance structure analysis: Conventional criteria versus new alternatives. Structural Equation Modeling: A Multidisciplinary Journal, 6, 1-55. doi:10.1080/10705519909540118 
lannarino, N. T., Veil, S. R., \& Cotton, A. J. (2015). Bringing home the crisis: How US evening news framed the 2011 Japan Nuclear crisis. Journal of Contingencies and Crisis Management, 23, 169-181. doi:10.1111/1468-5973.12068

ICM Crisis Report. (2013). Annual ICM crisis report: News coverage of business crisis during 2012. Institute for Crisis Management. Retrieved from http://crisisconsultant.com/wpcontent/uploads/2013/06/2012-Crisis-Report FINAL.pdf

Jacques, T. (2014). Issue and crisis management: Exploring issues, crises, risk and reputation. New York, NY: Oxford University Press.

Karp, A. (2013). Asiana Airlines Boeing 777-200ER crashes on landing. Air Transport World, August, 9.

Kim, H. J., \& Cameron, G. T. (2011). Emotions matter in crisis: The role of anger and sadness in the publics' response to crisis news framing and corporate crisis response. Communication Research, 38, 826-855. doi:10.1177/0093650210385813

Kim, J., Kim, H. J., \& Cameron, G. T. (2012a). Finding primary publics: A test of the third-person perception in corporate crisis situation. Journal of Public Relations, 24, 391-408. doi:10.1080/1062726X.2012.723275

Kim, J. N. (2006). Communicant activeness, cognitive entrepreneurship, and a situational theory of problem solving. Unpublished dissertation. University of Maryland, College Park.

Kim, J.-N., \& Grunig, J. E. (2011). Problem solving and communicative action: A situational theory of problem solving. Journal of Communication, 61, 120-149. doi:10.1111/jcom.2011.61.issue-1

Kim, J. N., Grunig, J. E., \& Ni, L. (2010). Reconceptualizing the communicative action of publics: Acquisition, selection, and transmission of information in problematic situation. International Journal of Strategic Communication, 4, 126-154. doi:10.1080/15531181003701913

Kim, J.-N., Hung-Baesecke, C. F., Yang, S.-U., \& Grunig, J. E. (2013). A strategic management approach to reputation, relationships, and publics: The research heritage of the excellence theory. In C. E. Carroll (Ed.), The handbook of communication and corporate reputation (pp. 197-212). Thousand Oaks, CA: SAGE.

Kim, J.-N., Jung, Y.-R., Park, S. C., \& Dutta, M. (2009, November). Gossiping science: Lay diffusers of science knowledge and information. Paper presented at the National Communication Association Convention, Chicago, IL.

Kim, J. N., \& Krishna, A. (2014). Publics and lay informatics: A review of the situational theory of problem solving. Communication Yearbook, 38, 71-106.

Kim, J. N., Ni, L., S.-H., K., \& Kim, J. R. (2012b). What makes people hot? Applying the situational theory of problem solving to hot-issue publics. Journal of Public Relations Research, 24, 144-164. doi:10.1080/1062726X.2012.626133

Kim, J.-N., Ni, L., \& Sha, B.-L. (2008). Breaking down the stakeholder environment: Explication approaches to the segmentation of publics of public relations research. Journalism and Mass Communication (J\&MC) Quarterly, 85, 751-768. doi:10.1177/107769900808500403

Kim, J.-N., \& Rhee, Y. (2012). Strategic communication about employee communication behavior (ECB) in public relations: Testing the models of megaphoning and scouting effects in Korea. Journal of Public Relations Research, 23, 243-268. doi:10.1080/1062726X.2011.582204

Kim, S., Kim, J.-N., Tam, L., \& Kim, G. T. (2014). Inquiring into activist publics in chronic environmental issues: Use of the mutual gains approach for breaking a deadlock. Journal of Public Affairs, Advance online publication. doi:10.1002/pa.1554.

Laufer, D., \& Jung, J. M. (2010). Incorporating regulatory focus theory in product recall communications to increase compliance with a product recall. Public Relations Review, 36, 147-151. doi:10.1016/j.pubrev.2010.03.004 
Lee, B. K. (2005). Hong Kong consumers' evaluation in an airline crash: A path model analysis. Journal of Public Relations Research, 17, 363-391. doi:10.1207/s1532754xjprr1704_3

Liu, B. F., Austin, L., \& Jin, Y. (2011). How publics respond to crisis communication strategies: The interplay of information form and source. Public Relations Review, 37, 345-353. doi:10.1016/j.pubrev.2011.08.004

Liu, B. F., \& Fraustino, J. D. (2014). Beyond image repair: Suggestions for crisis communication theory development. Public Relations Review, 40, 543-546. doi:10.1016/j.pubrev.2014.04.004

Liu, B. F., Jin, Y., \& Austin, L. (2013). The tendency to tell: Understanding publics' communicative responses to crisis information form and source. Journal of Public Relations Research, 25, 5167. doi:10.1080/1062726X.2013.739101

Liu, B. F., \& Kim, S. (2011). How organizations framed the 2009 H1N1 pandemic via social and traditional media: Implications for U.S. health communicators. Public Relations Review, 37, 233-244. doi:10.1016/j.pubrev.2011.03.005

Ni, L., \& Kim, J. N. (2009). Classifying publics: Communication behaviors and problem-solving characteristics in controversial issues. International Journal of Strategic Communication, 3, 217241. doi:10.1080/15531180903221261

Olsson, E.-K. (2014). Crisis communication in public organisations: Dimensions of crisis communication revisited. Journal of Contingencies and Crisis Management, 22, 113-125. doi:10.1111/jccm.2014.22.issue-2

Park, H., \& Hon, L. (2010, June). The association between South Korean citizens' perception of government crisis communication and the government-public relationship. Paper presented at the annual meeting of the International Communication Association, Singapore.

Procopio, C. H., \& Procopio, S. T. (2007). Do you know what it means to miss New Orleans? Internet communication, geographic community, and social capital in crisis. Journal of Applied Communication Research, 35, 67-87. doi:10.1080/00909880601065722

Reynolds, B., \& Seeger, M. W. (2005). Crisis and emergency risk communication as an integrative model. Journal of Health Communication, 10, 43-55. doi:10.1080/10810730590904571

Schwarz, A. (2012). How publics use social media to respond to blame games in crisis communication: The love parade tragedy in Duisburg 2010. Public Relations Review, 38, 430-437. doi:10.1016/j.pubrev.2012.01.009

Seeger, M. W. (2006). Best practices in crisis communication: An expert panel process. Journal of Applied Communication Research, 34, 232-244. doi:10.1080/00909880600769944

Seeger, M. W., \& Ulmer, R. R. (2001). Virtuous responses to organization crisis: Aaron Feuerstein and Milt Cole. Journal of Business Ethics, 31, 369-376. doi:10.1023/A:1010759319845

Simon, H. (2009). The crisis and customer behaviour: Eight quick solutions. Journal of Customer Behaviour, 8, 177-186. doi:10.1362/147539209X459796

Siomkos, G., \& Kurzbard, G. (1994). The hidden crisis in product-harm crisis management. European Journal of Marketing, 28, 30-41. doi:10.1108/03090569410055265

Spence, P. R., Westerman, D., Skalski, P. D., Seeger, M., Sellnow, T. L., \& Ulmer, R. R. (2006). Gender and age effects on information-seeking after 9/11. Communication Research Reports, 23, 217223. doi:10.1080/08824090600796435

Tucker, L., \& Melewar, T. (2005). Corporate reputation and crisis management: The threat and manageability of anti-corporatism. Corporate Reputation Review, 7, 377-387. doi:10.1057/palgrave.crr.1540233 
Turk, J. V., Jin, Y., Stewart, S., Kim, J., \& Hipple, J. R. (2012). Examining the interplay of an organization's prior reputation, CEO's visibility, and immediate response to a crisis. Public Relations Review, 38, 574-583. doi:10.1016/j.pubrev.2012.06.012

Ulmer, R. R., Sellnow, T. L., \& Seeger, M. W. (2014). Effective crisis communication: Moving from crisis to opportunity (3rd ed.). Thousand Oaks, CA: SAGE.

Utz, S., Schultz, F., \& Glocka, S. (2013). Crisis communication online: How medium, crisis type and emotions affected public reactions in the Fukushima Daiichi nuclear disaster. Public Relations Review, 39, 40-46. doi:10.1016/j.pubrev.2012.09.010

Van Der Meer, T. G. L. A. (2014). Organizational crisis-denial strategy: The effect of denial on public framing. Public Relations Review, 40, 537-539. doi:10.1016/j.pubrev.2014.02.005

Van Der Meer, T. G. L. A., Verhoeven, P., Beentjes, H., \& Vliegenthart, R. (2014). When frames align: The interplay between PR, news media, and the public in times of crisis. Public Relations Review, 40, 751-761. doi:10.1016/j.pubrev.2014.07.008

Vasquez, G. M., \& Taylor, M. (2001). Research perspectives on "the publics." In R. L. Heath (Ed.), Handbook of public relations (pp. 139-154). Thousand Oaks, CA: Sage.

Weiner, B. (1986). An attributional theory of motivation and emotion. New York, NY: Springer-Verlag. 